\section{Intestinal biopsy technique} Sir,

Drs. Townley and Barnes' article on 'Intestinal Biopsy in Childhood' (Archives, 1973, 48, 480) was of interest, but may I be allowed to offer some suggestions regarding the use of an outer guiding tube.

Some years ago I used a similar technique to the authors' but for some time I have been using an Argyle Salem Sump Tube $(10 \mathrm{FR}, 91 \mathrm{~cm}$, Sherwood Medical Products Ltd.) which has many advantages over the catheter tubing and other radio-opaque tubes. In the first instance it is sterile, disposabie, and radio-opaque, but strong and flexible enough to allow easy maneouvre. Secondly, since it incorporates a second suction tubing, one can obtain duodenal or jejunal secretions for bacteriological examination, tryptic activity etc., and, if required, perform a 'mini barium meal' which I have found useful on a number of occasions. In short, four tests can be performed at the price of one procedure.

J. A. KUZEMKO

Peterborough District Hospital, Peterborough PE3 6DA.

\section{Preparation for air travel in a child with sickle-cell anaemia}

Sir,

It is well recognized that people with sickle-cell anaemia tolerate reduced oxygen tension poorly. This makes general anaesthesia and high altitudes potentially dangerous. In the past, exchange transfusion has been used to overcome the dangers of anaesthesia (Macleod, 1969). We describe here a less dramatic method of altering the blood picture that can be used whenever there is 2 to 3 weeks' warning of the hypoxic episode. It depends on repeated small transfusions and the suppression of erythropoiesis.

A 5-year-old Nigerian girl with homozygous sickle-cell anaemia had been an inpatient for over a year after a sickle-cell crisis resulting in hemiplegia. As her parents found her disability intolerable, plans were made for her to return to her grandparents in Nigeria. The flight was in a $\mathrm{VC10}$, pressurized to at least $11 \mathrm{lb} / \mathrm{in}^{2}$. To protect the child during the flight, a series of transfusions was undertaken, starting 4 weeks before the flight. $\mathrm{Her} \mathrm{Hb}$ was usually about $7 \mathrm{~g} / 100 \mathrm{ml}$ and this was raised to $9 \cdot 8 \mathrm{~g}$ $/ 100 \mathrm{ml}$, with $200 \mathrm{ml}$ packed cells. A further transfusion of $200 \mathrm{ml}$ packed cells was given 11 days before the flight, and 2 days before departure $\mathrm{Hb}$ was still $9 \cdot 8 \mathrm{~g}$ $1100 \mathrm{ml}$. She was then transfused again to a $\mathrm{Hb}$ of $11 \cdot 2 \mathrm{~g} / 100 \mathrm{ml}$ so that her blood contained only $4 \%$ sickle cells. Cellulose acetate electrophoresis showed $73 \% \mathrm{Hb} \mathrm{A}, 24 \% \mathrm{Hb} \mathrm{S}$, and $3 \% \mathrm{Hb} \mathrm{A}_{2}$. She tolerated the flight well, and settled quickly into her extended family group.

This method of changing the blood picture of a homozygous sickler has been used before in preparation for cold surgery (Davis, 1971). It should be appreciated that by this method approximately $75 \%$ of the child's circulating red blood cells are rendered normal, while about $25 \%$ remain full of $\mathrm{Hb} \mathrm{S}$. This makes sickling unlikely, and hypoxia is safe for the week or two after the transfusions. After that erythropoiesis will restart and sickle $\mathrm{Hb}$ will again appear.

This state of $75 \%$ normal cells, $25 \%$ abnormal cells is in contrast to the condition of sickle-cell trait (heterozygous sickle-cell disease). In the latter all the cells are abnormal, each cell containing approximately $60 \% \mathrm{Hb} \mathrm{A}, 40 \% \mathrm{Hb}$ S. These cells must be exposed to considerable stress before they sickle, but obviously once sickling does occur all the cells are equally likely to succumb.

D. R. HARVEY and ALISON M. FRASER Department of Paediatrics, St. Charles's Hospital, London W10.

\section{REFERENCES}

Davis, L. R. (1971). Transfusion of children with homozygous haemoglobin-S disease. (Abst.) British fournal of Haematology, 21, 363.

Macleod, J. A. J. (1969). Exchange transfusion in a seven-year-old girl with sickle cell anaemia as preparation for adenoidectomy. Proceedings of the Royal Society of Medicine, 62, 1095. 